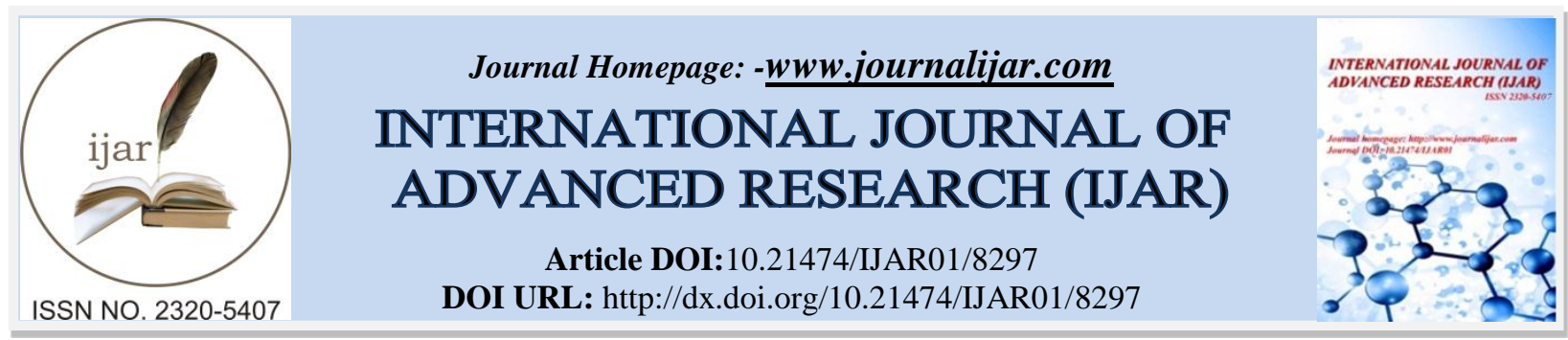

RESEARCH ARTICLE

\title{
EVALUATION OF MACRO NUTRIENT INTAKE OF NATIONAL FEMALE VOLLEYBALL PLAYERS AGED 10-18 YEARS.
}

Shivani Sharma ${ }^{1}$ and Anuradha Lehri ${ }^{2}$.

1. PhD Scholar, Department of Sports Science, Punjabi University, Patiala, Punjab-147002.

2. Assistant professor, Department of Sports Science, Punjabi University, Patiala, Punjab-147002.

\section{Manuscript Info}

Manuscript History

Received: 01 November 2018

Final Accepted: 03 December 2018

Published: January 2019

\section{Key words:-}

Anthropometry measurement, Dietary assessment, Nutrient adequacy ratio.

\begin{abstract}
The purpose of this study was to assess the Macronutrient intake of NationalFemale volleyball players. The players were provided with questionnaire to fill the general Information and 24-hour dietary recall. Anthropometric measurements include height and weight and BMI was calculated.Questionnaire method was adopted to collect the data. 24 dietary recall was employed to assess the macronutrient intake. Nutrient intake analysis did not include supplements. The results revealed that $31.2 \%$ of the total players fall in "underweight" Category. Only $7 \%$ and $3.1 \%$ Players fall under Overweight and Obese category respectively. The Nutrient adequacy ratio of all the nutrients among each age group (10-12 yrs, $13-15$ yrs and 16-18 yrs) is less than the required. The Intake of Carbohydrate and Protein is also less. Analyzing the BMI and Dietary Intake it was concluded that $31 \%$ of the players were underweight. On the other hand, the intake of Carbohydrate, Protein was very less as per the recommended dietary values for athletes. From the result it was concluded that the players have poor dietary intakes that place them at risk for nutritional shortages and compromised performance so they need professional counseling regarding nutrition practices for optimum health and performance.
\end{abstract}

Copy Right, IJAR, 2017, All rights reserved.

\section{Introduction:-}

Adolescent athletes have increased energy needs because of Vigorous physical activity and physical needs. This is true for the budding elite players, who exercise strenuously in order to maximize their performance. These athletes should consume high density food for both nutrients and kilocalories and to maintain their growth (1). Proper nutrition guidance and implementation is essential for optimizing athletic performance (2). Unfortunately, improper nutrition appears to be a common problem among young athletes because of lack of knowledge and availability.

Volleyball is one of the most popular team sports. Volleyball game is a combination of physical and mental capabilities such as explosive strength, agility, a high level of concentration and skill. volleyball is mostly relied on anaerobic system, the aerobic capacity of volleyball athletes is of critical importance because of the long duration of a volleyball game for recovery between points, stamina and tolerance to heat [3]. Training includes skill, strength

Corresponding Author:-Shivani Sharma.

Address:-PhD Scholar, Department of Sports Science, Punjabi University, Patiala, Punjab-147001. 
and conditioning programs. Proper nutrition advise is critical in order to enable the volleyball player to reach the peak performance and replace the lost energy (4).

The purpose of the present study was to analyze the macronutrient intake and to evaluate the nutrient adequacy of the diet of National female volleyball players.

\section{Material and Methods: -}

The subjects were members of a female volleyball team, which was ranked in the national division. The study was conducted on Junior Female volleyball Players aged 10-18 Years in the City Yamuna nagar, where National tournament of Volleyball. Consent to collect the data was taken from the respective coaches of the team. The sample was consisted of 128 Players from all over India. Height and weight were recorded with Anthropometric rod and Weighing scale and BMI (body mass index) was calculated. 24 Hour dietary recall method was employed to assess the macronutrient intake. Nutrient intake analysis did not includesupplements, because the aim of the study was to evaluate the adequacy ofdietary intake.

\section{Statistical analysis:-}

Data coding, entry and validation was done. The data was analyzed through comparison between Dietary Intake to the Total Energy Expenditureof the players. Total Energy Expenditure was estimated from calculations of Basal Metabolic Rate according to Harris Benedict Equation and the Activity factor. Percent adequacy and NutrientAdequacy Ratio (NAR)was calculated.

$\mathrm{NAR}=$ Amount of nutrient in diet / RDA for that nutrient [5].

Nutrient Adequacy Ratio Classification:-

\begin{tabular}{|r|r|}
\hline NAR & RESULT \\
\hline Greater than 1 & Requirement is met \\
\hline Slightly less than 1 & Still sufficient (77\% requirement is met) \\
\hline Very less than 1 & Needs are not met \\
\hline
\end{tabular}

\section{Results and Discussion: -}

The mean age of the female footballers was 14.6+1.5 years. Height and Weight was recorded and BMI (Body mass index) calculated. The mean height and weight of the subjects were $159.9 \pm 7.3 \mathrm{~cm}$ and $49.9 \pm 8.1 \mathrm{~kg}$ respectively.

Table 1:-Body Mass Index (BMI) of the subjects

\begin{tabular}{|c|c|c|c|c|c|}
\hline CLASSIFICATION & $\begin{array}{l}\text { BMI } \\
\text { (Asians) }\end{array}$ & $\begin{array}{ll}\begin{array}{l}10-12 \\
(N=11)\end{array} & \text { Years } \\
\end{array}$ & $\begin{array}{ll}13-15 & \text { Years } \\
(\mathrm{N}=79) & \end{array}$ & $\begin{array}{l}\begin{array}{l}16-18 \\
(N=38)\end{array} \\
\end{array}$ & $\begin{array}{l}\text { Total } \\
\text { N }(\%)\end{array}$ \\
\hline Underweight & $<18$ & 4 & 25 & 11 & $40(31.2)$ \\
\hline Normal & $18-22.9$ & 7 & 46 & 22 & 75 (58.5) \\
\hline Overweight & $23.0-24.9$ & 0 & 5 & 4 & $9(7)$ \\
\hline Obese & $>25$ & 0 & 3 & 1 & $4(3.1)$ \\
\hline
\end{tabular}

Table 1 shows the BMI Classification according to the age groups. It revealed that $31.2 \%$ of the total players fall under "underweight" Category. Only $7 \%$ and $3.1 \%$ Players fall under Overweight and Obese category respectively.

Table 2:-Daily Mean Intake of Macronutrients, Nutrient Adequacy Ratio and Percent Adequacy with Recommended Nutrient values for athletes.

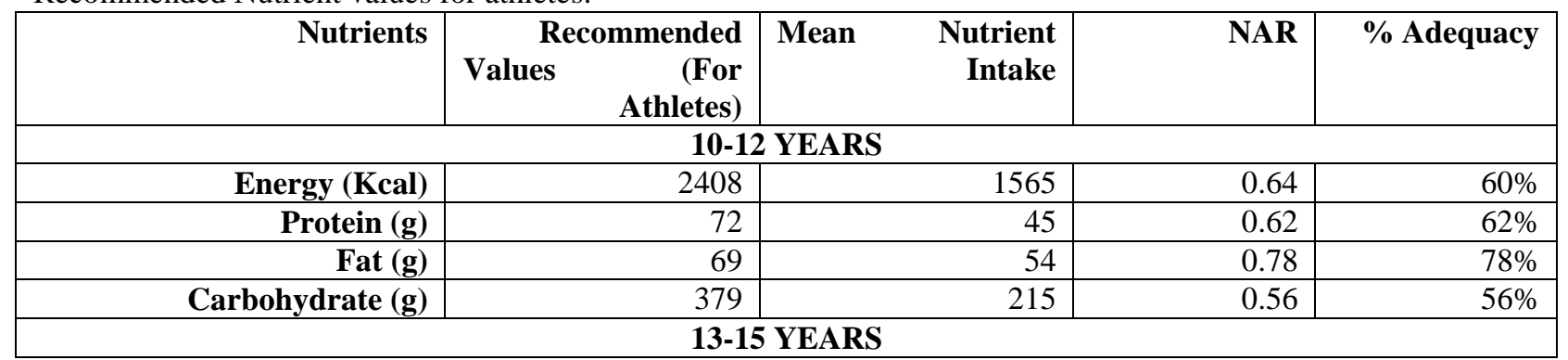




\begin{tabular}{|r|r|r|r|r|}
\hline Energy (Kcal) & 2425 & 1608 & 0.66 & $66 \%$ \\
\hline Protein (g) & 73 & 50 & 0.68 & $68 \%$ \\
\hline Fat (g) & 67 & 53 & 0.79 & $79 \%$ \\
\hline Carbohydrate (g) & 382 & 222 & 0.58 & $58 \%$ \\
\hline \multicolumn{7}{|c|}{$\mathbf{1 6 - 1 8}$ YEARS } \\
\hline Energy (Kcal) & 2493 & 1677 & 0.67 & $67 \%$ \\
\hline Protein (g) & 75 & 50 & 0.66 & $66 \%$ \\
\hline Fat (g) & 69 & 61 & 0.88 & $88 \%$ \\
\hline Carbohydrate (g) & 393 & 231 & 0.58 & $58 \%$ \\
\hline
\end{tabular}

Amount of Protein, Fat and Carbohydrate was Calculated from the IOC Guidelines of Sports Nutrition [6]

The macronutrient intake was calculated and compared with Recommended Nutrient Values [6] for athletes of Female volleyball players in the age group of 10-12, 13-15 years and 16-18 years. Table 2 Depicts that the Nutrient adequacy ratio of all the nutrients among each age group is less than the required. The Intake of Carbohydrate and Protein is also less. Analyzing the BMI and Dietary Intake it was concluded that $31 \%$ of the players were underweight. On the other hand, the intake of Carbohydrate, Protein was very less as per the recommended dietary values for athletes. Poor intake of nutrients in the diet affects the nutritional status thereby performance.

\section{Discussion:-}

There are few Indian studies specifically on the Nutrient intake, Knowledge and Implementation of it to maximize the performance and proper growth of the individual.In the present study we have examined Macronutrient intake and nutrient adequacy ratio of the national female volleyball players aged 10-18 Years. The major findings of the study were that the nutrient intake is very less than the recommended amount required for the players. Similarly, most of the dietary surveys carried out on volleyball (7) and other court sports (8) have reported low energy intake by athletes. Low energy intake and its associated risks were higher among female athletes (7). According to Coyle, the predominant source of energy is carbohydrates, and that is why the carbohydrate depletion is often the reason for fatigue during exercise (9). Athletes should consume a high percentage of carbohydrates. The author states that low consumption of energy is witnessed in players. Protein intake was also low in this study, as the requirement of athlete is high for protein especially adolescent athletes [10]. From the study, it was concluded that specific nutritional knowledge should be imparted to the players to maximize their performance.

\section{References:-}

1. Brownell, K., and J. Rodin. Eating, Body Weight and Performance in Athletes. Philadelphia: Lea and Febiger, 1992.

2. Costill, D.L. Inside Running: Basics of Sports Physiology. Indianapolis, IN: Benchmark Press, 1986.

3. Scates A.E. Winning Volleyball. Dubuque, IA: Brown \& Benchmark, 1993.

4. GB. Carey, "Nutrition: the winning diet," in Science of Coaching Volleyball, C.McGown, Ed., pp. 130-160, Human Kinetics, Champaign, IL, 1994.

5. Margret D.simko, Catherine cowell, Judith A. gil bride, nutrition assessment: a Comprehensive guide for planning intervention, II edition, aspen publication, page no. 180

6. Potgieter S, BScDietetics, MNutrition- Sport nutrition: A review of the latest guidelines for exercise and sport nutrition from the American College of Sport Nutrition, the International Olympic Committee and the International Society for Sports Nutrition,2013

7. Anderson DE. The impact of feedback on dietary intake and body composition of college women volleyball players over a competitive season. Journal of strength and conditioning research / National Strength \& Conditioning Association. 2010;24(8):2220-6.

8. Hickson JF, Jr., Schrader J, Trischler LC. Dietary intakes of female basketball and gymnastics athletes. J Am Diet Assoc. 1986;86(2):251-3.

9. Coyle, E.F. Carbohydrate feedings: effects on metabolism, performance and recovery. Med. Sport Sci. 32:1-14, 1991.

10. Tipton KD, Wolfe RR. Protein and amino acids for athletes. Journal of sports sciences. 2004;22(1):65-79. 